\title{
ТЕХНОЛОГИЯ ПРОЕКТИРОВАНИЯ РАСПОЛОЖЕНИЯ ПЛОЩАДОК НАКОПЛЕНИЯ ТВЕРДЫХ КОММУНАЛЬНЫХ ОТХОДОВ
}

\section{Анастасия Сергеевна Умербаева}

Сибирский государственный университет геосистем и технологий, 630108, Россия, г. Новосибирск, ул. Плахотного, 10, обучающийся, тел. (996)924-12-79, e-mail: nastena.samsonova.2018@bk.ru

\section{Андрей Геннадиевич Шарикалов}

Мэрии города Новосибирска, 630099, Россия, г. Новосибирск, ул. Трудовая, 1, заместитель начальника отдела охраны окружающей среды департамента энергетики, жилищного и коммунального хозяйства города, тел. (383)228-88-17, e-mail: asharikalov@admnsk.ru

\section{Алексей Викторович Дубровский}

Сибирский государственный университет геосистем и технологий, 630108, Россия, г. Новосибирск, ул. Плахотного, 10, кандидат технических наук, зав. кафедрой кадастра и территориального планирования, тел. (383)361-01-09, e-mail: avd5@ssga.ru

\section{Анатолий Викторович Ершов}

Сибирский государственный университет геосистем и технологий, 630108, Россия, г. Новосибирск, ул. Плахотного, 10, кандидат технических наук, старший преподаватель кафедры кадастра и территориального планирования, тел. (383)361-01-09, e-mail: er-tos@inbox.ru

\section{Анастасия Леонидовна Ильиных}

Сибирский государственный университет геосистем и технологий, 630108, Россия, г. Новосибирск, ул. Плахотного, 10, кандидат технических наук, доцент кафедры кадастра и территориального планирования, тел. (383)361-01-09, e-mail: linykh_al@mail.ru

Новосибирск - один из наиболее крупных центров научного и технического развития, занимающий третье место по территории и численности населения в Российской Федерации. На сегодняшний день в частном секторе Новосибирска и Новосибирской области остро стоит вопрос о недостаточной оснащенности территории мусорными баками и специализированными площадками, что в свою очередь ведет к ряду других проблем в области экологической безопасности. В данной статье подробно рассмотрены причины возникновения сложившейся ситуации и пути ее решения. В ходе работы был разработан проект по созданию новых площадок накопления твердых коммунальных отходов. При выполнении работ используется геоинформационная система с картой-схемой размещения мест уже существующих (площадок) накопления твердых коммунальных отходов, совмещённая с кадастровым планом территории и проектом планировки и застройки.

Ключевые слова: геоинформационная система, площадки накопления твердых коммунальных отходов, земельные участки, кадастровый план территории, экологическая безопасность

\section{TECHNOLOGY FOR DESIGNING THE LOCATION OF MUNICIPAL SOLID WASTE STORAGE SITES}

\section{Anastasia S. Umerbaeva}

Siberian State University of Geosystems and Technologies, 10, Plakhotnogo St., Novosibirsk, 630108, Russia, Student, phone: (996)924-12-79, e-mail: nastena.samsonova.2018@bk.ru 


\section{Andrey G. Charikalov}

Novosibirsk City Hall, 630099, Novosibirsk, Trudovaya 1, Deputy head of the environmental protection Department of the Department of energy, housing and utilities of the city, phone: (383)228-88-17, e-mail: asharikalov@admnsk.ru

\section{Alexey V. Dubrovsky}

Siberian State University of Geosystems and Technologies, 10, Plakhotnogo St., Novosibirsk, 630108, Russia, Ph. D., Head of the Department of Cadastre and Territorial Planning, phone: (383)361-01-09, e-mail: avd5@ssga.ru

\section{Anatoly V. Ershov}

Siberian State University of Geosystems and Technologies, 10, Plakhotnogo St., Novosibirsk, 630108, Russia, Ph. D., Associate Professor, Department of Cadastre and Territorial Planning, phone: (383)361-01-09, e-mail: er-tos@inbox.ru

\section{Anastasia L. Ilyinykh}

Siberian State University of Geosystems and Technologies, 10, Plakhotnogo St., Novosibirsk, 630108, Russia, Ph. D., Associate Professor, Department of Cadastre and Territorial Planning, phone: (383)344-31-73, e-mail: linykh_al@mail.ru

Novosibirsk is one of the largest centers of scientific and technical development, occupying the third place in terms of territory and population in the Russian Federation. To date, the private sector in Novosibirsk and the Novosibirsk region is facing an acute problem of insufficient equipment of the territory with garbage cans and specialized sites, which in turn leads to a number of other problems in the field of environmental and technosphere safety. This article discusses in detail the causes of this situation and ways to solve it. During the work, a project was developed to create new sites. When performing works, a geoinformation system is used with a map-scheme for the placement of places (sites) for the accumulation of solid municipal waste, combined with a cadastral plan of the territory and a project for planning and development.

Keywords: geoinformation system, municipal solid waste storage sites, land plots, cadastral plan of the territory, environmental and technosphere safety

В результате мониторинга в 2020 году министерство ЖКХ и энергетики предоставило данные, согласно которым общая потребность города Новосибирска и его области в мусорных контейнерах оценена в 50 тыс. штук. Основная часть приходится на территории малонаселенных пунктов и частного сектора. Подобная ситуация ведет к ухудшению экологического состояния населенных пунктов и затрудняет ведение жилищного и коммунального хозяйства. Согласно данным экологического надзора участились случаи появления несанкционированных свалок в местах общего пользования, что отрицательно сказывается на ведении городского хозяйства и на социальной сфере жизнедеятельности населения. Для решения данной проблемы был разработан проект планировки схем расположения будущих площадок ТКО, разработанный в геоинформационной системе MapInfo Professional 12.0 на основе кадастрового плана территории. Полученные результаты научной работы будут применены в создании геоинформационной базы данных о месторасположении и количестве площадок ТКО. Актуальной задачей является определение мест расположения будущих площадок с учетом правил пользования территорий населенных пунктов. 
Исходными данными для проекта служат следующие слои: Здания, Общий буфер (20 метров), Дороги, Новые площадки ТКО, Контейнерные площадки, Земельные участки, Границы районов, Частный сектор.

Согласно нормам СанПина 2.1.2.2645-10 установка мусорных баков производится на расстоянии от 20 до 100 м от зданий. Красной линией окружности, радиусом 100 м, обозначены здания, относящиеся к какому-либо контейнеру, в центре располагается площадка ТКО, рис. 1.

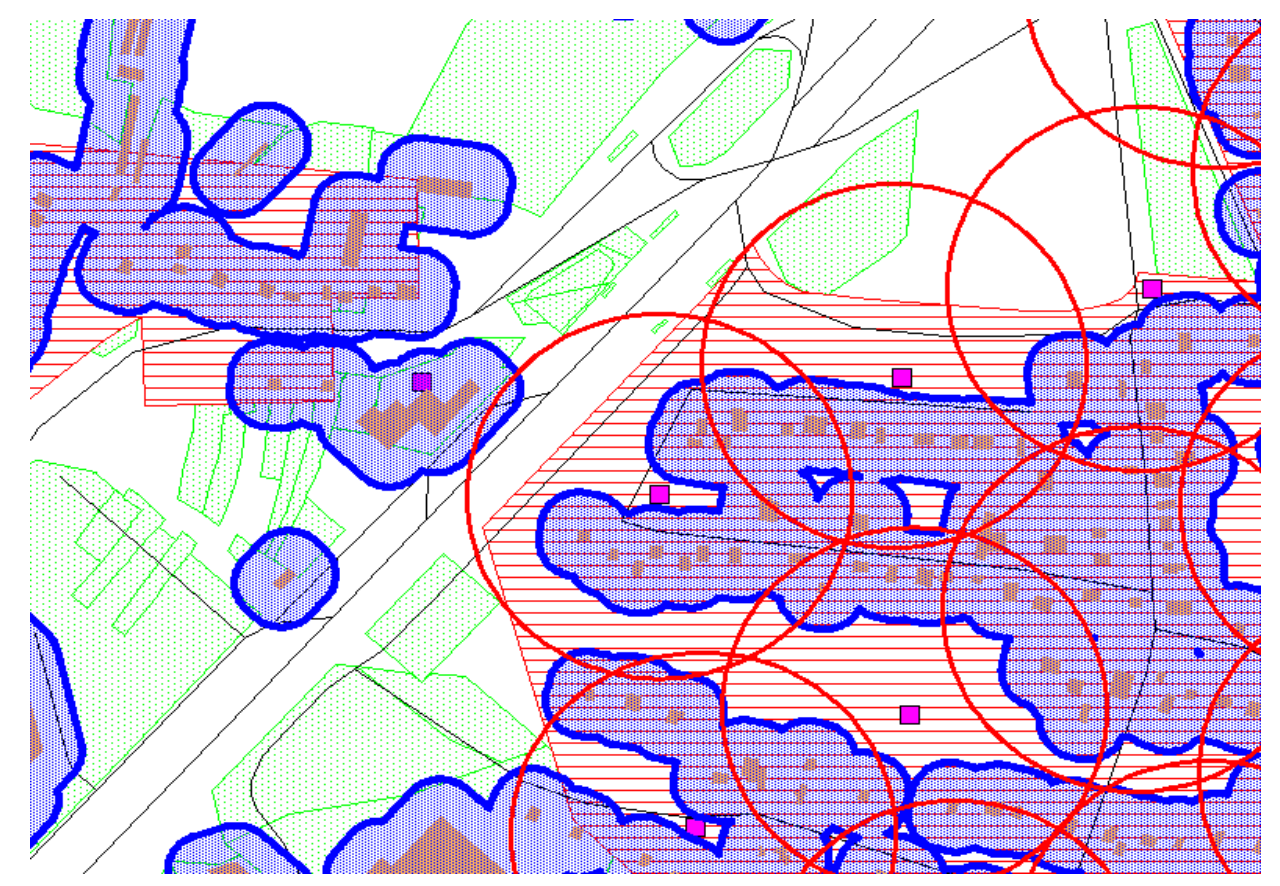

Рис. 1. Запроектированные площадки ТКО в радиусе 100 метров

Улицы частного сектора не имеют достаточной ширины, вследствие чего происходит наложение буферных зон, рис. 2.

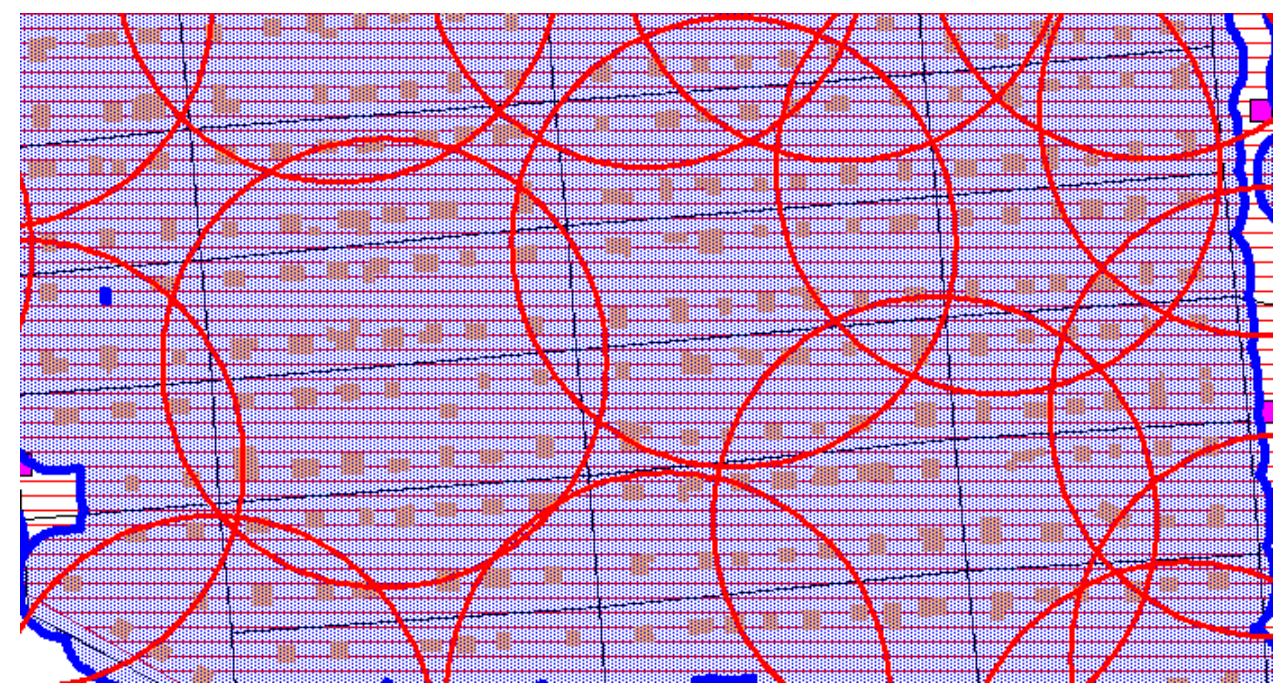

Рис. 2. Наложение буферных зон 
Из-за отсутствия места для установки контейнеров, примерно $20 \%$ зданий и земельных участков частного сектора не относятся ни к одной мусорной площадке.

В этих районах проблема решается путем вывоза мусора. На территории Новосибирска сбором, утилизацией и переработкой твердых коммунальных отходов занимается региональный оператор «Экология-Новосибирск».

При определении схемы расположения необходимо также учитывать санитарные зоны линий коммуникаций, расположенных в непосредственной близости от зданий. С точными критериями можно ознакомиться в Постановлении Главного государственного санитарного врача РФ от 14.03.2002 №10 «О введении в действии Санитарных зон», согласно которому:

- охранные зоны тепловых сетей - это земельные участки, вдоль трасс прокладки тепловых сетей естественного откоса грунта, шириной определяемой углом естественного откоса угла, но не менее 3 метров в каждую сторону, считая от края строительных конструкций тепловых сетей или от наружной поверхности изолированного теплопровода бесканальной прокладки;

- санитарная зона линий водопровода - участки по обе стороны от линии водопровода (при отсутствии грунтовых вод - не менее 10 м при диаметре водоводов до 1000 мм и не менее 20 м при диаметре водоводов более 1000 мм;

- вдоль воздушных линий электропередачи - в виде части поверхности участка земли и воздушного пространства; для линий с самонесущими или изолированными проводами, проложенных по стенам зданий, конструкций и т.д.

- для трасс наружных газопроводов - рассстояние 2 м с каждой стороны газопровода.

Учитывая все необходимые требования возможно произвести векторизацию только лишь $80 \%$ территории частного сектора Новосибирска. В оставшейся части необходимо проектировать без соблюдения норм в условиях сформировавшейся застройки.

Общее количество площадок, необходимых для мусора, составляет порядка 849 штук. Закупкой и установкой мусорных контейнеров занимаются органы местного самоуправления, также приобретение и установка производится из средств регоператора, равным $1 \%$ от валовой выручки. По подсчетам работа будет завершена к 2023 году.

\section{БИБЛИОГРАФИЧЕСКИЙ СПИСОК}

1. Управление отходами. Сточные воды и биогаз полигонов захоронения твердых бытовых отходов / под ред. Я. И. Вайсмана. - Пермь: Пермский нац. исслед. политехнический унт, 2012. $-258 \mathrm{c}$.

2. Предложения по совершенствованию системы охраны и мониторинга земель полигонов твердых бытовых отходов / А. О. Грекова, А. В. Дубровский, Я. Г. Пошивайло, Г.А. Уставич // Интерэкспо ГЕО-Сибирь. XIV Междунар. науч. конгр., 23-27 апреля 2018 г., Новосибирск : Междунар. науч. конф. «Экономическое развитие Сибири и Дальнего Востока. Экономика природопользования, землеустройство, лесоустройство, управление недвижимостью» : сб. материалов в 2 т. Т. 2. - Новосибирск : СГУГиТ, 2018. - С. 107-112.

3. Дубровский А. В., Пошивайло А. О. К вопросу влияния загрязнения городских земель на кадастровую стоимость недвижимости // ГЕО-Сибирь-2016 : СГГА, 2016. - С. 39-43. 
4. Город в мусоре. Как в Новосибирске борются со стихийными свалками [Электронный ресурс]: Еженедельник «Аргументы и Факты», № 49, АиФ на Оби 05/12/2018 - Режим доступа: http://www.nsk.aif.ru/gazeta/number/39277. - Загл. с экрана.

5. Акумов А. И. Состояние окружающей среды и заболеваемость населения в Новосибирске / А.И. Акумов, И.Ф. Мингазов - Новосибирск: «Наука», 1999. С. 52-53.

6. Об отходах производства и потребления [Электронный ресурс]: Федеральный закон от 24.06.1998 №89-Ф3 (ред. от 29.06.2015) (с изменениями и дополнениями вступ. в силу c 01.07. 2015г.) - Режим доступа: http://www.consultant.ru/ (C КонсультантПлюс.

7. Об охране окружающей среды. Федеральный Закон РФ № 7-ФЗ от 10.01.2002 [Электронный ресурс]. - Режим доступа: http://www.consultant.ru/ (C КонсультантПлюс.

8. Инструкция по проектированию, эксплуатации и рекультивации полигонов для твердых бытовых отходов. Утверждена министерством строительства 02.11. 1996 г. - М.: Академия коммунального хозяйства им. К. Д. Памфилова, 1998. - 110 с.

9. Гигиенические требования к устройству и содержанию полигонов для твердых бытовых отходов [Электронный ресурс] Санитарные правила СП 2.1.7.1038-01утв. постановлением Главного государственного санитарного врача РФ от 30 мая 2001 г. № 16 - Режим доступа: https://base.garant.ru/12123803/.- Загл. с экрана.

10. Принципы управляемого восстановления территорий размещения отходов / А. Д. Потапов, О. В. Тупицина, А. Н. Сухоносова, А. А. Савельев, Б. М.

11. Гришин, К. Л. Чертес // Известия высших учебных заведений. Строительство, № 5, 2014. - C.98-108.

12. Ильиных А. Л., Клюшниченко В. Н., Межуева Т. В. К вопросу о методическом обеспечении кадастровой оценки недвижимости // Интерэкспо ГЕО-Сибирь. XIV Междунар. науч. конгр. : Междунар. науч. конф. «Экономическое развитие Сибири и Дальнего Востока. Экономика природопользования, землеустройство, лесоустройство, управление недвижимостью» : сб. материалов в 2 т. (г. Новосибирск, 23-27 апреля 2018 г.). - Новосибирск : СГУГиТ, 2018. T. 2. - C. 214-223.

13. Шеина С. Г., Бабенко Л. Л. Выбор участка размещения полигона твердых бытовых отходов и факторы, учитываемые при принятии решений // Интернет-журнал Науковедение, № 5 (18), 2013. - М.: ИЦ «Науковедение», 2013. - С. 1-5.

14. Уставич Г.А., Дубровский А.В., Пошивайло Я.Г., Грекова А.О., Малыгина О.И. Элементы методики рационального землепользования территории полигонов твердых бытовых отходов. - Вестник СГУГиТ. - Том 24, № 3, 2019.- С. 203-221.

(C) А. С. Умербаева, А. Г. Шарикалов, А. В. Дубровский, А. В. Ершов, А. Л. Ильиных, 2021 